\title{
Keterbatasan dan Kendala-Kendala dalam Prediksi Penggunaan Lahan Masa Depan Menggunakan Metode Cellular Automata (Studi Kasus Pemodelan Prediksi Penggunaan Lahan DAS Darang Tahun 2015) Ahmad Cahyadi $^{1}$, Dhandhun Wacano ${ }^{2}$, Ardila Yananto ${ }^{3}$ dan Muh Sufwandika Wijaya ${ }^{4}$

\author{
${ }^{1,2}$ Magister Perencanaan Pengelolaan Pesisir dan Daerah Aliran Sungai (MPPDAS) Fakultas Geografi \\ Universitas Gadjah Mada Yogyakarta \\ 3,4Jurusan Kartografi dan Penginderaan Jauh Fakultas Geografi Universitas Gadjah Mada Yogyakarta \\ $\underline{1 \text { ahmadcahyadi@geo.ugm.ac.id }}$
}

\begin{abstract}
ABSTRAK
Perubahan penggunaan lahan merupakan salah satu hal yang sangat penting untuk dianalisis dalam menilai dampak pembangunan terhadap kondisi lingkungan, sumberdaya, dan risiko bencana. Penelitian ini bertujuan untuk (1) melakukan prediksi perubahan penggunaan lahan di DAS Garang pada Tahun 2015, dan (2) mengetahui keterbatasan dan kendala-kendala dalam aplikasi pemodelan perubahan penggunaan lahan menggunakan cellular automata. Data yang digunakan adalah data penggunaan lahan yang diekstrak dari citra Tahun 1994, citra 2001 dan citra 2008 menggunakan software ENVI. Prediksi penggunaan lahan pada Tahun 2015 di DAS Garang dilakukan dengan menggunakan metode Cellular Automata menggunakan software IDRISI, sedangkan analisis keterbatasan dan kendala pemanfaatan metode Cellular Automata dilakukan dengan analisis deskriptif. Hasil analisis menunjukkan bahwa pada Tahun 2015 penggunaan lahan tambak, permukiman dan lahan pertanian memiliki luas yang semakin bertambah, sedangkan penggunaan lahan hutan dan kebun campuran luasnya semakin kecil. Keterbatasan dari metode cellular automata adalah tidak dapat mengakomodasi keberadaan pusat perkembangan kota baru, seperti berdirinya kampus, pusat pertokoan dan sebagainya dan hanya menggunakan regresi linier sehingga hasilnya akan sesuai dengan kecenderungan dari citra multitemporal yang digunakan dalam analisis. Selain itu model ini tidak dapat mengakomodasi perembetan kota meloncat (leap frog development) Kendala dari pemanfaatan metode ini adalah dibutuhkannya data multitemporal, minimal tiga periode. Hal ini cukup mnenyulitkan mengingat perolehan data ini cukup sulit dan mahal.
\end{abstract}

Kata Kunci: Penggunaan Lahan, Cellular Automata, Keterbatasan

\section{PENGANTAR}

Daerah Aliran Sungai (DAS) adalah suatu wilayah daratan yang merupakan satu kesatuan dengan sungai dan anak-anak sungainya, yang berfungsi menampung, menyimpan dan mengalirkan air yang berasal dari curah hujan ke danau atau ke laut secara alami, yang batas di darat merupakan pemisah topografis dan batas di laut sampai dengan daerah perairan yang masih terpengaruh aktivitas daratan (PP Nomor 37 Tahun 2012). Berdasarkan penelitian tersebut, maka kemudian DAS sering pula disebut sebagai system hidrologi (Asdak, 2007). Hal ini bararti bahwa DAS terdiri dari komponen-komponen sistem yang dapat saling mempengaruhi, atau dapat pula dijelaskan bahwa perubahan pada suatu bagian sistem dapat mempengaruhi system yang llain meskipun secara keruangan terpisah cukup jauh.

Pengelolaan DAS didefinisikan sebagai upaya manusia dalam mengatur hubungan timbal balik antara sumberdaya alam dengan manusia di dalam DAS dan segala aktivitasnya, agar terwujud kelestarian dan keserasian ekosistem serta meningkatnya kemanfaatan sumberdaya alam bagi manusia secara berkelanjutan (PP Nomor 37 Tahun 2012). Namun demikian, Departemen Kehutanan (2009) menyebutkan bahwa pengelolaan DAS pada prinsipnya adalah pengaturan tata guna lahan atau optimalisasi penggunaan lahan untuk berbagai kepentingan secara rasional serta praktek lainnya yang ramah lingkungan sehingga dapat dinilai dengan indikator kunci (ultimate indicator) kuantitas, kualitas dan kontinuitas aliran sungai pada titik pengeluaran (outlet) DAS. Berdasarkan hal tersebut maka berarti faktor penggunaan lahan memiliki peranan yang penting dalam pengelolaan DAS.

Kajian tentang perubahan penggunaan lahan di suatu DAS telah banyak dilakukan. Kebanyakan dari kajian tersebut dilakukan dengan menggunakan data penginderaan jauh multi temporal minimal pada dua masa atau waktu. Kajian tersebut mampu untuk menggambarkan perubahan penggunaan lahan pada suatu periode waktu tertentu, trend perubahan penggunaan lahan, kecenderungan perubahan penggunaan lahan serta pertumbuhan atau penyusutan setiap penggunaan lahan per tahun pada wilayah yang dikaji. Selain itu, kajian tersebut dapat melakukan prediksi luasan masing-masing penggunaan lahan pada masa mendatang. Namun demikian prediksi yang dibuat belum dapat menjelaskan sebaranj spasial perubahan penggunaan lahan yang akan terjadi pada masa mendatang. Oleh karena itu, maka penelitian ini mencobba melakukan kajian tentang pemodelan penggunaan lahan pada masa mendatang dengan menggunakan metode Cellular Automata, di mana model ini dapat memprediksi secara spasial perubahan penggunaan 
lahan pada masa mendatang. Makalah ini juga membahas tentang keterbatasan dan kendala-kendala pemanfaatan metode Cellular Automata untuk prediksi penggunaan lahan pada masa mendatang.

\section{METODOLOGI}

\subsection{Alat dan bahan}

Alat dan bahan yang digunakan dalam penelitian ini meliputi:

a. Citra Landsat TM 1994 dan Citra Landsat ETM perekaman Tahun 200, serta citra ALOS AVNIR perekaman Tahun 2008 dengan liputan DAS Garang dan Sekitarnya;

b. Peta Rupa Bumi Indonesia (RBI) skala 1:25.000 dengan liputan DAS Garang; serta

c. Software ENVI 4.5; Idrisi Andes; dan ArcGIS 9.3.

\subsection{Cellular Automata-Markov Chain}

Metode cellular automata adalah salah satu dari aplikasi sistem informasi geografis (SIG) yang dapat digunakan untuk membangun suatu model, dalam penelitian ini digunakan untuk membangun model penggunaan lahan pada masa mendatang. Metode ini merupakan salah satu bentuk dari simulasi spasial (geosimulation). Pemodelan CA digunakan untuk mengetahui kedinamisan suatu obyek/fenomena, dalam penelitian ini digunakan untuk mengetahui dinamika penggunaan lahan. Kedinamisan yang dimaksud dalam hal ini adalah suatu wujud perubahan dari objek yang dikaji (de Almeida dkk, 2002; dan Deliar 2010). Suatu automaton (A) diwujudkan dalam kumpulan state yang terbatas $S=$ $\left\{S_{1}, S_{2}, S_{3}, \ldots, S n\right)$ dan sekumpulan transisi $(T)$. Sehingga A secara geometrik sama dengan $(\sim)$ yang dipengaruhi oleh kondisi $\mathrm{S}$ dan $\mathrm{T}$.

\section{$A \sim(S, T)$}

Penerapan CA dalam konteks geografis S, T dan kondisi ketetanggaan akan menstimulus $A$. Kondisi tersebut akan menyebabkan terjadinya suatu bentuk relasi spasial antara pixel. Dengan adanya faktor ketetanggaan yang mempengaruhi A maka secara geometrik suatu automaton dapat dirumuskan menjadi lebih terperinci, yaitu terdiri dari automaton $(A)$, state $(S)$, transisi $(T)$ dan faktor ketetanggaan $(N)$.

keterangan:

$$
A \sim(S, T, N)
$$

$\begin{array}{ll}\mathrm{A} & =\text { automaton } \\ \mathrm{S} & =\text { state }(\text { kelas) } \\ \mathrm{T} & =\text { transition rules (aturan transisi) } \\ \mathrm{N} & =\text { neighborhood (ketetanggaan) }\end{array}$

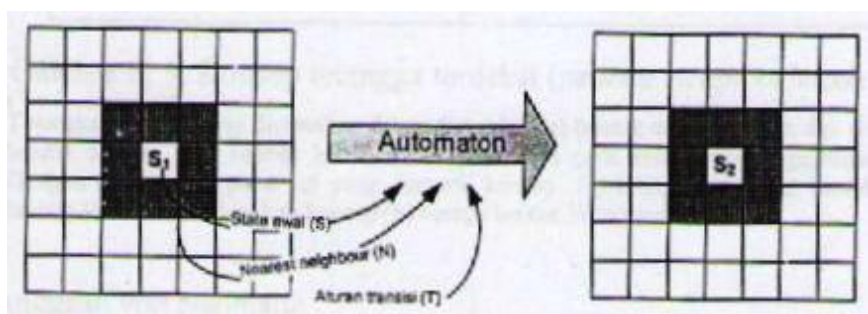

Gambar 1. Konsep Cellular Automata (Sumber : Deliar, 2010 dalam )

\subsection{Hasil Pemodelan Cellular Automata}

\section{HASIL DAN DISKUSI}

Hasil pemodelan penggunaan lahan di DAS Garang pada Tahun 2015 menggunakan metode cellular automata menunjukkan bahwa penggunaan lahan berupa lahan terbangun dan lahan pertanian mengalami penambahan yang cukup besar, sedangkan penggunaan/penutuplahan berupa kebun campur dan hutan mengalami penurunan. Gambar 1 menunjukkan bahwa pengurangan penggunaan/ penutup lahan berupa kebun campur dan hutang banyak terjadi di bagian tengah dan hilir DAS Garang. Hal ini dapat dimengerti karena wilayah ini memiliki topografi yang lebih cocok untuk permukiman dan pertanian dibandingkan wilayah bagian hulu yang merupakan bagian dari lereng tengah dan lereng atas dari Gunungapi Ungaran. 


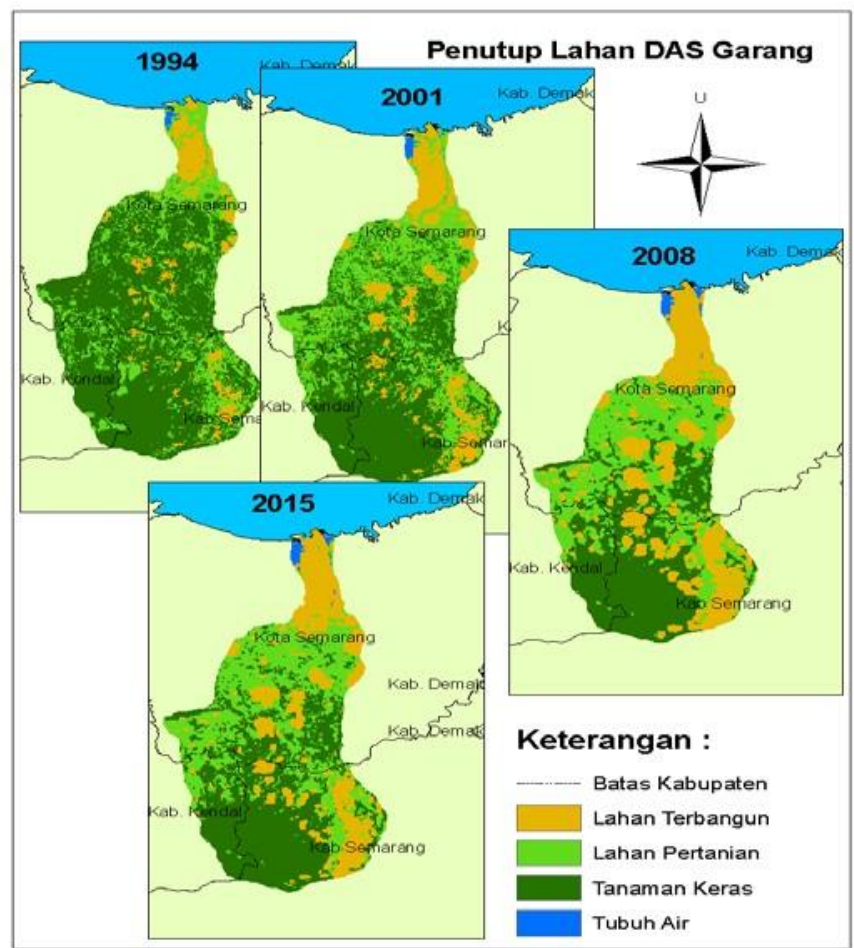

Gambar 2. Perubahan Penutup Lahan pada tahun 1994,2001, 2008, dan 2015

Tabel 1. Perubahan Luasan Penutup Lahan untuk Tiap Tahunnya

\begin{tabular}{|c|c|c|c|c|}
\hline \multirow{2}{*}{ Penggunaan Lahan } & \multicolumn{4}{|c|}{ Luas Penggunaan Lahan $\left(\mathrm{km}^{2}\right)$} \\
\hline & Tahun 1994 & Tahun 2001 & Tahun 2008 & Tahun 2015 \\
\hline Lahan Terbangun & 20.60 & 34.03 & 48.82 & 63.14 \\
\hline Lahan Pertanian & 49.92 & 67.48 & 69.38 & 65.89 \\
\hline $\begin{array}{c}\text { Tanaman Keras } \\
\text { (Hutan/Kebun Campur) }\end{array}$ & 134.33 & 102.96 & 85.78 & 74.81 \\
\hline Tubuh Air (Kolam/Tambak) & 0.76 & 1.14 & 1.64 & 1.78 \\
\hline LUAS TOTAL & 205.61 & 205.61 & 205.61 & 205.61 \\
\hline
\end{tabular}

Perubahan penggunaan/penutup lahan yang terjadi ini akan memiliki pengaruh terhadap kondisi DAS Garang, khususnya terkait dengan karakteristik hidrologi DAS tersebut. Cahyadi dkk (2012a) menyebutkan bahwa perubahan penggunaan lahan/penutup lahan akan menyebabkan semakin besarnya debit puncak di DAS Garang, meskipun pengaruhnya tidak terlalu besar. Kondisi tersebut terjadi karena koefisien runoff dari DAS Garang semakin besar. Cahyadi dkk (2012b) juga menjelaskan bahwa perubahan penggunaan/penutup lahan dengan pola demikian akan menyebabkan kapasitas maksimum retensi air oleh tanah di DAS Garang akan turun. Kondisi tersebut menyebabkan semakin banyaknya air hujan yang berubah menjadi runoff dan semakin sedikit air hujan yang meresap ke dalam tanah menjadi input bagi airtanah.

\subsection{Keterbatasan dan Kendala Pemanfaatan Model Cellular Automata}

Meskipun mampu melakukan prediksi penggunaan lahan dengan memunculkan sebaran spasialnya, metode ini masih memiliki beberapa keterbatasan yang harus diperhatikan dalam penggunaannya. Hal ini penting terkait dengan hasil yang ingin dicapai dari suatu pemodelan. Beberapa keterbatasan dari model cellular automata adalah sebagai berikut:

a. Model ini melakukan prediksi berdasarkan perkembangan linier dari data masukan. Karena hanya menggunakan dua citra multi temporal, maka trend perubahan akan mengikuti data masukan. Kondisi ini merupakan kelemahan karena pada kenyataannya perubahan penggunaan lahan tidak selalu berjalan dengan kecepatan konstan;

b. Model ini tidak dapat mengakomodasi perkembangan yang disebabkan oleh pusat perkembangan kota yang baru, misalnya berdirinya suatu tempat perbelanjaan, sekolah, universitas, pasar dan sebagainya; dan 
c. Model ini hanya dapat memfasilitasi model perembetan kota dengan pola konsentris (concentric development/ low density continous development) dan perembetan memanjang (ribbon development/linear development/axial development), namun tidak dapat menggambarkan perembetan kota dengan pola meloncat (leap frog development/checkerboard development) (Yunus, 2008).

Selain itu, pemanfaatan metode cellular automata seringkali terkendala ketersediaan data temporal dengan spesifikasi yang sama (misal citra satelit yang sama dengan tahun yang berbeda). Padahal metode ini hanya dapat dilakukan dengan minimal dua data multitemporal (apabila hasil pemodelan dikoreksi dengan koreksi lapangan penggunaan pada tahun penelitian/tidak dengan citra yang lain). Selain itu, seringkali data terbaru dari penggunaan lahan hanya dapat diperoleh dengan biaya yang mahal.

\begin{abstract}
4.KESIMPULAN
Model Cellular automata memiliki kelebihan berupa kemampuan menampilkan prediksi penggunaan lahan pada masa mendatang secara spasial. Meskipun demikian, metode ini memiliki beberapa keterbatasan dan kendala dalam pemanfaatannya. Keterbatasan dari metode cellular automata adalah tidak dapat mengakomodasi keberadaan pusat perkembangan kota baru, seperti berdirinya kampus, pusat pertokoan dan sebagainya dan hanya menggunakan regresi linier sehingga hasilnya akan sesuai dengan kecenderungan dari citra multitemporal yang digunakan dalam analisis. Selain itu model ini tidak dapat mengakomodasi perembetan kota meloncat (leap frog development) Kendala dari pemanfaatan metode ini adalah dibutuhkannya data multitemporal, minimal tiga periode. Hal ini cukup mnenyulitkan mengingat perolehan data ini cukup sulit dan mahal.
\end{abstract}

\title{
5. REFERENSI
}

Asdak, C., 2007, Hidrologi dan Pengelolaan Daerah Aliran Sungai Edisi IV, Yogyakarta: Gadjah Mada University Press.

Cahyadi, A.; Nugraha, H., Nurjani, E.; Yananto, A. dan Wijaya, M.S. 2012b, Using Remote Sensing Multi-temporal Image to Analysis of Land Use Changes and Its Impact On The Peak Discharge In Garang Watershed Central Java, Jurnal Matematika Sains dan Teknologi Universitas Terbuka (Submited).

Cahyadi, A.; Yananto, A.; Wijaya, M.S. dan Nugraha, H., 2012b, Analisis Pengaruh Perubahan Penggunaan Lahan Terhadap Retensi Potensial Air oleh Tanah pada Kejadian Hujan Sesaat (Studi Kasus Perubahan Penggunaan Lahan di DAS Garang Jawa Tengah), Prosiding Seminar Nasional "Peran Geoinformatika dalam Pengelolaan Sumber Daya Alam Indonesia", 30 Juni 2012, Jurusan Teknik Informatika UPN Veteran Yogyakarta.

de Almeida, C.M.; Batty, M.; Monteiro, A.M.V.; Camara, G.; Soares-Filho, B.S.; Cerqueira, G.C. dan Pennachin, C.L., 2003, Stochastic Cellular Automata Modeling of Urban Land Use Dynamics: Empirical Development and Estimation, Computers, Environment and Urban Systems, 27. Hal: 481-509.

Deliar, Albertus. 2010. Pemodelan Hibrid Dalam Prediksi Dinamika Perubahan Tutupan Lahan (Studi Kasus: Wilayah Bandung). Disertasi. Bandung: Teknik Geodesi dan Geomatika, Institut Teknologi Bandung.

Kementerian Kehutanan Republik Indonesia, 2009, Kerangka Kerja Pengelolaan Daerah Aliran Sungai di Indonesia, Jakarta.

Peraturan Pemerintah Republik Indonesia Nomor 37 Tahun 2012 Tentang Pengelolaan Daerah Aliran Sungai

Yunus, H.S., 2008, Struktur Tata Ruang Kota, Yogyakarta: Pustaka Pelajar. 